\title{
KOMUNIKASI INTERPERSONAL PUSTAKAWAN \\ DALAM MEMBERIKAN PELAYANAN KEPADA PEMUSTAKA DI UNIVERSITAS NEGERI I GUSTI BAGUS SUGRIWA DENPASAR
}

\author{
Wayan Ngurah Eka Kurniawan $\underline{a}, 1$ \\ Kadek Agus Wardana $\underline{a}$ \\ a Universitas Hindu Negeri I Gusti Bagus Sugriwa Denpasar \\ 1 Corresponding Author, email: Ngurahwayan536@gmail.com (Kurniawan)
}

\section{ARTICLE INFO}

Article history:

Received: 11-07-2021

Revised:13-08-2021

Accepted: 17-09-2021

Published: 30-09-2021

\section{Keywords:}

Interpersonal

Communication,

Librarian, In

Providing Services

\section{ABSTRACT}

\begin{abstract}
Librarians are an important part of a school or university. Given that the library is a learning center that functions as an agent of social change that improves the quality of life by meeting the information needs of the community, especially students, it is felt necessary to discuss the interpersonal communication of librarians. The success of a communication depends a lot on the ability and insight of the librarian as the person who conveys the message, who is involved in determining the success or failure of a communication. The existence of a library in an educational environment is an important supporting facility for the implementation of the learning process at the institution. Especially in the university environment as one of the supports in the Tri Dharma of Higher Education, namely education, research, and community service. This article uses a descriptive qualitative research method that is supported by a literature study. This study finds that the Interpersonal communication is needed in the process to achieve the goals of the librarian in the context of the success of the library in fulfilling its overall function. The aspect of fishing with interpersonal communication is the most important aspect. The librarian's interpersonal communication in serving the visitors at the Hindu State University I Gusti Bagus Sugriwa Denpasar looks good, although there are still obstacles in interpersonal communication, especially in conveying a librarian's message which is sometimes not accepted or cannot be understood by those served in the library. This can be overcome by structured team work and trainings that have been carried out.
\end{abstract}

\section{PENDAHULUAN}

Perpustakaan adalah pusat pembelajaran yang berfungsi sebagai agen perubahan sosial yang meningkatkan kualitas kehidupan dengan memenuhi kebutuhan informasi masyarakat (Perpusnas, 2009:6). Perpustakaan merupakan pusat dan sumber belajar serta sarana penelitian yang mempunyai tugas pokok dalam penyediaan, pengelolaan, dan pelayanan informasi bagi pemustaka. Dalam proses pelayanan perpustakaan tidak terlepas dari kegiatan komunikasi. Dalam pelayanan perpustakaan, pustakawan memegang peranan penting, karena ia merupakan ujung tombak pelayanan yang berhubungan langsung dengan 
pemustaka yang membutuhkan informasi. Trimo (1987: 100) mengatakan, sukses tidaknya pelayanan perpustakaan, 75\% ditentukan oleh peran sebagai konsultan dari staf bersangkutan.

Perpustakaan perguruan tinggi sebagai pusat informasi dan pusat pembelajaran, tentu menyediakan berbagai macam pelayanan yang menuntut terjadinya komunikasi terhadap stakeholders (komunikasi ilmiah). Komunikasi ilmiah mencakup berbagai aspek seperti layanan sirkulasi, layanan referensi, periodikal, jurnal cetak, jurnal online, layanan karya ilmiah. Layanan-layanan tersebut dilengkapi dengan koleksi-koleksi yang bervariasi dan berkualitas meliputi fiksi, non fiksi, kamus, ensiklopedia, jurnal, majalah, koleksi karya ilmiah yang dihasilkan oleh sivitas akademika dan laporan ilmiah seperti primer avenue yang berisi ide-ide ilmiah dan penemuan-penemuan ilmiah di kalangan ilmuwan.

Dengan koleksi beragam tersebut, perpustakaan mampu menjadi media untuk mentransfer ilmu pengetahuan yang terkandung dalam setiap lembaran buku, jurnal, majalah kepada pemustaka melalui komunikasi ilmiah. Proses komunikasi ilmiah berlangsung ketika pemustaka (mahasiswa, dosen, masyarakat umum, ilmuwan) mengakses koleksi perpustakaan kemudian menjadikannya sebagai bahan rujukan dalam mengerjakan tugas kuliah, menulis karya ilmiah ataupun artikel.

Kesan pertama yang muncul dalam benak pemustaka, akan berimbas pada kesan terhadap perpustakaan, sehingga kualitas pelayanan yang baik menjadi acuan bagi staf dan pustakawan dalam melayani pemustaka. Untuk itu diperlukan adanya keterampilan komunikasi yang dapat menciptakan hubungan yang harmonis antara pustakawan sebagai penyampai informasi dengan pemustaka sebagai individu yang membutuhkan informasi.

Kemampuan komunikasi yang harus dimiliki oleh pustakawan antara lain kemampuan komunikasi interpersonal. Komunikasi interpersonal merupakan interaksi tatap muka antara dua atau beberapa orang: pengirim dapat menyampaikan pesan secara langsung dan penerima pesan dapat menerima dan menanggapi pesan itu secara langsung (Hardjana 2003). Namun, pada kenyataannya, komunikasi interpersonal sering kali dianggap sebagai hal kecil karena dilakukan sehari-hari. Padahal, komunikasi interpersonal dapat menentukan citra diri dan reputasi seseorang. Oleh karena itu, komunikasi interpersonal adalah kemampuan dasar yang harus dimiliki oleh setiap manusia. Dalam tulisan ini penulis akan menguraikan konsep pustakawan dalam memberikan pelayanan kepada publik baik dosen, mahasiswa maupun masyarakat umum di Universitas Negeri I Gusti Bagus Sugriwa.

\section{METODE PENELITIAN}

Metode yang dimaksud adalah cabang ilmu yang mempelajari cara-cara melakukan pengamatan yaitu meliputi kegiatan - kegiatan mencari, mencatat, merumuskan, menganalisa sampai menyusun laporan berdasarkan faktafakta atau gejala-gejala secara ilmiah. Melaksanakan suatu penelitian untuk mendapatkan data yang valid dan konsisten, maka diperlukan adanya metode sehingga hasil yang diperoleh dapat dipertanggung jawabkan secara ilmiah (Narbuko, 2003 : 03).

Penelitian ini menggunakan metode penelitian kualitatif dan penekatan library study. Dalam tradisi penelitian kualitatif, proses penelitian dan ilmu pengetahuan tidak sesederhana yang terjadi pada penelitian kuantitatif, karena sebelum hasil-hasil penelitian kualitatif memberi sumbangan kepada ilmu pengetahuan, tahapan penelitian kualitatif melampaui berbagai tahapan berpikir kritisilmiah, maka seorang peneliti memulai berpikir secara induktif, yaitu menangkap berbagai fakta atau fenomena sosial melalui pengamatan di lapangan kemudian menganalisisnya dan kemudian berupaya melakukan teorisasi berdasarkan yang diamati. Pemilihan informan merupakan tindakan yang utama dalam proses 
penelitian dan merupakan pertimbangan untuk pengumpulan data.

Teknik pemilihan informan yang digunakan dalam penelitian ini adalah purposive sampling, yaitu teknik pemilihan yang sengaja mencari peserta dengan karakter tertentu, sesuai dengan kebutuhan untuk mengembangkan analisis dan memunculkan teori (Morse 2004). Dalam penelitian ini, data dikumpulkan dengan menggunakan wawancara mendalam dan observasi. Metode keputakaan digunakan untuk melengkapi data-fata untuk kemudian dianalisis dan diinterpretasi.

\section{HASIL DAN PEMBAHASAN}

Perpustakaan berasal dari kata pustaka berarti buku, kitab. Dalam bahasa Inggris dikenal dengan istilah library. Perpustakaan adalah sebuah ruangan, bagian sebuah gedung, ataupun gedung itu sendiri yang digunakan untuk menyimpan buku dan terbitan lain yang biasanya disimpan menurut tata susunan tertentu untuk digunakan pembaca, bukan untuk dijual (Sulistyo-Basuki, 1993:3). Sutarno (2004:10) menegaskan sebuah perpustakaan harus memenuhi persyaratan tertentu yaitu:

a) Adanya kumpulan buku-buku dan bahan pustaka lainnya, baik tercetak maupun terekam.

b) Ditata menurut suatu sistem tertentu, diolah/diproses meliputi: registrasi, dan identifikasi, katalogisasi, klasifikasi, dan dilengkapi dengan perlengkapan koleksi, seperti slip buku, kartu-kartu katalog, kantong buku dan lainnya.

c) Ditempatkan di gedung atau ruangan tersendiri, sebaiknya tidak disatukan dengan kantor atau kegiatan yang lain.

d) Dikelola atau dijalankan oleh petugaspetugas, dengan persyaratan tertentu yang melayani pemakai dengan sebaik-baiknya.

e) Ada masyarakat pemakai perpustakaan tersebut baik untuk membaca, meminjam, meneliti, menggali, menimba dan mengembangkan ilmu pengetahuan yang diperoleh di perpustakaan.

f) Perpustakaan merupakan institusi yang bermitra terhadap proses penyelenggaraan pendidikan secara langsung dan tidak langsung baik formal maupun nonformal.

Berdasarkan pengertian di atas, dapat disimpulkan bahwa perpustakaan dapat diartikan sebuah ruangan atau gedung, di dalamnya terdapat kumpulan buku yang mengandung informasi mengenai ilmu pengetahuan. Buku-buku tersebut diproses menurut aturan tertentu selanjutnya ditata dan disusun di rak buku. Selain itu perpustakaan seyogyanya dikelola oleh petugas yang mempunyai kemampuan, keterampilan serta menguasai/ paham ilmu pengetahuan di bidang perpustakaan, selanjutnya bertugas untuk melayani kebutuhan informasi para pengguna perpustakaan. Sedangkan seorang pustakawan menurut Undang-Undang Republik Indonesia Nomor 43 Tahun 2007 pasal 1 ayat 8, pustakawan adalah seseorang yang memiliki kompetensi, yang diperoleh melalui pendidikan dan atau pelatihan kepustakawanan, serta mempunyai tugas dan tanggung jawab untuk melaksanakan pengelolaan dan pelayanan perpustakaan.

Kata pustakawan berasal dari kata "pustaka". Dengan demikian penambahan kata "wan" berarti orang yang pekerjaannya atau profesinya terkait erat dengan dunia pustaka atau bahan pustaka. Menurut IPI (Ikatan Pustakawan Indonesia) sebagai organisasi yang menghimpun para pustakawandalam kode etiknya menyatakan bahwa pustakawan adalah seseorang yang melaksanakan kegiatan perpustakaan dengan jalan memberikan pelayanan kepada masyarakat sesuai dengan tugas lembaga induknya berdasarkan ilmu pengetahuan, dokumentasi dan informasi yang diperolehnya melalui pendidikan. 
Dalam IFLA/UNESCO PUblic Library Manifesto (1994) dijelaskan bahwa pustakawan adalah perantara aktif antara pemustaka dan sumber daya sehingga pendidikan profesional dan berkelanjutan yang dimiliki pustakawan sangat diperlukan untuk memastikan layanan yang memadai. Perpustakaan umum adalah pelayanan yang ditujukan untuk anggota masyarakat yang memiliki kebutuhan bervariasi dan berubah. Pustakawan perpustakaan umum dituntut untuk memiliki berbagai keterampilan dan kualitas, termasuk keterampilan interpersonal, kesadaran sosial, kerja sama tim, dan kepemimpinan serta kompetensi dalam praktik dan prosedur organisasi (The Public Library Service: IFLA/ UNESCO Guidelines for Development 2001). IFLA juga menjelaskan bahwa kompetensi yang dibutuhkan pustakawan perpustakaan umum sebagai berikut.

1. Kemampuan untuk berkomunikasi secara positif dengan orang lain.

2. Kemampuan unuk memahami kebutuhan pemustaka.

3. Kemampuan untuk bekerja sama dengan individu dan kelompok di masyarakat.

4. Pengetahuan dan pemahaman akan keanekaragaman budaya.

5. Pengetahuan tentang materi yang membentuk koleksi perpustakaan dan cara mengaksesnya.

6. Pemahaman tentang dan simpati pada prinsip layanan publik.

7. Kemampuan untuk bekerja dengan orang lain dalam menyediakan layanan perpustakaan yang efektif.

8. Keterampilan organisasi, dengan fleksibilitas untuk mengidentifikasi dan menerapkan perubahan.

9. Imajinasi, visi, dan keterbukaan terhadap gagasan dan praktik baru.

10. Kesiapan untuk mengubah metode kerja untuk memenuhi situasi baru.
11. Pengetahuan tentang teknologi informasi dan komunikasi.

Perpustakaan perguruan tinggi Universitas Negeri I Gusti Bagus Sugriwa Denpasar sebagai perpustakaan akademik memainkan peran yang sangat penting dalam pelaksanaan tri dharma suatu perguruan tinggi. Perpustakaan perguruan tinggi sangat diperlukan untuk penelitian, pengajaran dan pembelajaran, serta pengabdian kepada masyarakat. Ditinjau dari lokasinya, perpustakaan perguruan tinggi biasanya berlokasi di tengah kampus dan dianggap sebagai "jantung perguruan tinggi". Dalam Undang-Undang Perpustakaan Nomor 43 Tahun 2007, pasal 24 disebutkan perpustakaan perguruan tinggi sebagai berikut:

1. Setiap perguruan tinggi menyelenggarakan perpustakaan yang memenuhi standar nasional perpustakaan dengan memperhatikan Standar Nasional Pendidikan.

2. Perpustakaan dimaksud pada ayat (1) memiliki koleksi, baik jumlah judul maupun jumlah eksemplarnya, yang mencukupi untuk mendukung pelaksanaan pendidikan, penelitian, dan pengabdian kepada masyarakat.

3. Perpustakaan perguruan tinggi mengembangkan layanan perpustakaan berbasis teknologi informasi dan komunikasi.

4. Setiap perguruan tinggi mengalokasikan dana untuk pengembangan perpustakaan sesuai dengan peraturan perundangundangan guna memenuhi standar nasional pendidikan dan perpustakaan."

Komunikasi adalah inti semua hubungan sosial, apabila orang telah mengadakan hubungan tetap, maka sistem komunikasi yang mereka lakukan akan menentukan apakah sistem tersebut dapat mempererat atau mempersatukan mereka, mengurangi ketegangan atau melenyapkan persengketaan 
apabila muncul (Widjaja, 1993:4). Komunikasi menjadi suatu fenomena bagi terbentuknya suatu masyarakat atau komunitas yang terintegrasi oleh informasi, di mana masingmasing individu dalam masyarakat itu saling berbagi informasi (information sharing) untuk mencapai tujuan.

Proses komunikasi pada hakikatnya adalah proses penyampaian pikiran atau perasaan oleh seseorang kepada orang lain (Effendy, 2011:11). Secara umum, komunikasi merupakan bagian penting yang mendukung keberadaan suatu organisasi termasuk perpustakaan. Tanpa komunikasi di perpustakaan, maka tidak mungkin terjadi transmisi ilmu pengetahuan dalam masyarakat terutama pemustaka. Dengan demikian, suatu kegiatan tidak mungkin dapat dilakukan tanpa adanya komunikasi. Hal ini menunjukkan bahwa komunikasi sangatlah penting terutama di lingkungan perpustakaan.

Komunikasi interpersonal disebut juga komunikasi antarpribadi, yang merupakan interaksi tatap muka antara dua atau beberapa orang tempat pengirim menyampaikan pesan secara langsung dan penerima pesan menerima dan menanggapi secara langsung (Hardjana 2003). Pendapat lain menyebutkan bahwa komunikasi interpersonal adalah komunikasi antara orang-orang yang bertatap muka, yang memungkinkan setiap pesertanya menangkap reaksi orang lain secara langsung, baik secara verbal maupun nonverbal (Mulyana 2005).

Sementara itu, menurut DeVito (2014) komunikasi interpersonal adalah interaksi verbal atau nonverbal yang terjadi antara dua orang yang telah memiliki hubungan yang jelas, yang terhubungkan dengan beberapa cara, seperti komunikasi yang terjadi antara bapak dan anak, dokter dan pasien, guru dan murid. Jadi, dapat disimpulkan bahwa komunikasi interpersonal adalah interaksi yang berlangsung antara dua atau beberapa orang yang terjadi pertukaran pesan baik verbal atau nonverbal.
Komunikasi interpersonal pustakawan pada instansi perguruan tinggi pada Universitas Negeri Gusti Bagus Sugriwa dalam upaya meningkatkan pelayanan pengunjung, diharapkan dapat memberikan keputusan kondisional yang bermanfaat bagi pengunjung, sehingga dapat mengubah pengetahuan, sikap dan perilaku mereka, serta secara tidak langsung dapat menjadi kontribusi bagi pengembangan perpustakaan. Oemi Abdurrahman (1995:61) komunikasi dapat dibagi tiga, yaitu :

1. Menyebarkan informasi, yaitu menyebarkan pesan yang dibutuhkan agar dapat dimengerti sehingga dapat mengambil keputusan yang tepat.

2. Melakukan persuasif, yaitu tindakan yang berdasarkan segi-segi psikologis yang dapat membangkitkan kesadaran individu

3. Melaksanakan Koersif, yaitu suatu sikap atau tindakan yang bersifat memaksa yang dilakukan dengan menunjukan kekuasaan dan cara-cara lain untuk mempengaruhi, pengetahuan sikap, dan tingkah laku individu.

Berdasarkan definisi Devito, maka komunikasi antarpribadi (komunikasi antar persona) adalah komunikasi yang terjadi secara dialogis, dimana saat seorang komunikator berbicara maka akan terjadi umpan balik dari komunikan sehingga terdapat interaksi. Dalam komunikasi dialogis, baik komunikator maupun komunikan, keduanya aktif dalam proses pertukaran informasi yang berlangsung dalam interaksi.

Komunikasi antara pustakawan dan pemustaka merupakan hal yang tidak dapat dihindari dan cukup intens terjadi dalam layanan perpustakaan. Pelayanan publik yang disediakan perpustakaan merupakan sarana membangun komunikasi ilmiah dengan semua pihak baik internal maupun eksternal perpustakaan. Pemustaka merupakan pihak eksternal perpustakaan. Pelayanan sirkulasi dan 
layanan referensi merupakan bagian layanan publik yang berhubungan langsung dengan pemustaka, dalam konteks ini terjadi konsultasi antara pustakawan dan pemustaka. Komunikasi ini terjalin dalam rangka penelusuran informasi pemustaka guna mendapatkan informasi yang relevan sesuai dengan kebutuhan pemustaka.

Pustakawan tetap berusaha bersikap suportif walaupun sedang memiliki masalah pribadi. Sikap itu dimaksudkan untuk menciptakan suasana yang nyaman, yang fleksibel dan membantu para pemustaka melalui komunikasi interpersonal. Meskipun sedang memiliki masalah, pustakawan akan tetap dapat melayani pemustaka dengan baik dan sopan. Komunikasi interpersonal yang efektif menciptakan keberhasilan pustakawan di Perpustakaan Universitas Negeri Igusti Bagus Sugriwa Denpasar sehingga pemustaka yang datang ke perpustakaan tidak merasa diawasi oleh pustakawan dan ingin kembali lagi ke perpustakaan. Pada hakikatnya komunikasi antar pribadi adalah komunikasi antara seorang komunikator dengan komunikan. Dimana dalam perpustakaan pustakawan bertindak sebagai komunikator sedangkan pemustaka bertindak sebagai komunikan. Jenis komunikasi tersebut dianggap mampu mengubah sikap, pendapat atau perilaku masyarakat/pemustaka.

Tercipta suasana kebersamaan antara pembicara dan pendengar ketika pembicara berkomunikasi dengan sikap kebersamaan. Artinya, pembicara itu menyampaikan rasa ketertarikan dan perhatian, keinginan dan daya tarik kepada pendengar. Sikap ramah dari pustakawan membuat pemustaka merasa nyaman dan tidak segan bertanya kepada pustakawan. Ketika pustakawan berkomunikasi dengan pemustaka, tercipta kebersamaan antara pembicara dan pendengar yang terlihat dari keramahan yang ditunjukkan oleh pustakawan dalam membantu kesulitan pemustaka. Pustakawan juga memfokuskan pada pertanyaan dan kebutuhan pemustaka untuk kemudian memberikan umpan balik (feedback) verbal dan nonverbal yang tepat, seperti dengan menanyakan kembali kepada pemustaka apa lagi yang perlu dibantu oleh pustakawan.

Dalam konteks perpustakan UHN I Gusti Bagus Sugriwa Denpasar tampak memang pelayanan yang optimal. Hal ini sesuai dengan kewajiban yang memang harus dipenuhi oleh seorang pustakawan. Seorang pustakwan wajib mengembangkan sikap penuh perhatian (mindfulness) kepada pemustakanya. Itulah salah satu sikap profesional seorang pustakawan karena yang dihadapi pustakawan adalah manusia yang senantiasa memerlukan perhatian orang lain dalam memenuhi segala kebutuhan informasi yang dicarinya. Meskipun pustakawan di Perpustakaan Universitas Negeri Igusti Bagus Sugriwa Denpasar belum sepenuhnya menerapkan orientasi kepada pemustaka (users oriented), mereka yang bertugas di pelayanan sirkulasi Perpustakaan Universitas Negeri Igusti Bagus Sugriwa Denpasar telah berusaha mengembangkan salah satu sikap profesional, dengan memberikan perhatian penuh kepada pemustaka yang mengalami kesulitan.

Tidak kalah penting bagi seorang pusktakawan dalam menyikapi era modern seperti sekarang ini, bagi seorang pustakwan dalam memahami Strategi komunikasi yang digunakan oleh pustakawan adalah dengan munggunakan model-model literasi informasi yang diterapakan dalam implementasi literasi informasi dengan menggunakan model tersebut mahasiswa dan dosen paham akan penggunaan dan pemanfaatan e-resources secara optimal. Melimpahnya informasi di internet membuat pustakawan dan pemustaka harus menjelajah banyak web portal dan memerlukan waktu yang lama untuk mendapatkan informasi yang dibutuhkan. Diperlukan strategi menelusur dan skill teknologi untuk mendapatkan sumber informasi yang tepat yang tersedia di internet. 
Literasi informasi merupakan pondasi dalam menelusur informasi secara cepat dan tepat. Keterampilan literasi informasi yang melekat pada pencari informasi/mahasiswa akan membawa kesuksesan dalam pendidikan formalnya, membekali mereka untuk menjadi pembelajar seumur hidup, dan problem solver. Dan bisa memajukan nama lembaga dimana pustakawan itu bekerja.

\section{SIMPULAN}

Dari studi ini dapat ditarik kesimoulan bahwa Perpustakaan Universitas Negeri Igusti Bagus Sugriwa Denpasar dapat memenuhi komitmen dalam berupaya meningkatkan pelayanan dan keramahan kepada semua anggotanya, keterampilan berkomunikasi menjadi prioritas utama. Pustakawan dapt menyadari bahwa bimbingan diberikan apabila ada pemustaka yang kebingungan karena pertama kali datang ke perpustakaan dan tidak mengetahui cara memanfaatkan fasilitas penelusuran informasi yang ada di Perpustakaan Universitas Negeri I Gusti Bagus Sugriwa Denpasar. Memang layanan di kampus Universitas Negeri I Gusti Bagus Sugriwa Denpasar sudah cukup baik, tetapi akan lebih baik lagi apabila pustakawan lebih proaktif dan berinisiatif untuk menanyakan kepada pemustaka sebelum mereka mengalami kesulitan.

Strategi komunikasi interpersonal memang tampak sangat nyata dikembangkan di UHN IGB Sugriwa Denpasar. Mulai dari sikap terbuka terhadap lawan bicara yang sangat berpengaruh di dalam menumbuhkan komunikasi interpersonal yang efektif antara pustakawan dan pemustaka. Hal ini dilakukan mengingat perpustakaan dapat dikatakan baik apabila berhasil memberikan informasi yang dibutuhkan pemustakanya, maka Perpustakaan Universitas Negeri Igusti Bagus Sugriwa Denpasar, dalam hal ini pustakawan, harus bersikap terbuka: mempelajari perilaku pencari informasi di Perpustakaan Universitas Negeri I Gusti Bagus Sugriwa Denpasar. Hal ini sesuai dengan kompetensi yang dibutuhkan pustakawan perpustakaan umum menurut IFLA, yaitu imajinasi, visi, dan keterbukaan terhadap gagasan dan praktik baru serta kemampuan untuk bekerja dengan orang lain dalam menyediakan layanan perpustakaan yang efektif.

\section{DAFTAR PUSTAKA}

Abdurrahman, Oemi. 2001. Dasar-Dasar Public Relations. Bandung : PT Citra Aditya Bakti.

De Vito, Joseph A. 2014. The Interpersonal Communication Book. Edisi ke-13. New York: Harper Collins.

Effendy, O.U. (2011). Ilmu Komunikasi: Teori dan Praktek, Bandung: Rosdakarya.

Hardjana, Agus M. 2003. Komunikasi Intrapersonal dan Komunikasi Interpersonal. Yogyakarta: Kanisius.

IFLA. 2001. The Public Library Service: IFLA/UNESCO Guidelines for Development. Munchen: IFLA Publications.

Perpusnas [Perpustakaan Nasional RI]. (2009). UU Nomor 43 Tahun 2007. Jakarta: Perpustakaan Nasional RI.

Sulistyo-Basuki,. (1993). Pengantar IImu Perpustakaan, Jakarta: Gramedia.

Sutarno NS. (2004). Manajemen Perpustakaan: Suatu Pendekatan Praktik, Jakarta: Samitra Media Utama.

Trimo, Soejono. (1985). Pedoman Pelaksanaan Perpustakaan. Bandung: Remadja Rosdakarya.

Widjaja, A.W. (2000). Ilmu Komunikasi: Pengantar Studi, Ed. Revisi, Jakarta: Rineka Cipta.[online]. Diakses dari shorturl.at/cjFM5, tanggal 20 Juni 2020. 